\title{
Oje Kullanımının Eldeki Bakteriyel Üreme Üzerine Etkisi
}

\section{Effect of Use of Nail Polish on Hand Bacterial Colonization}

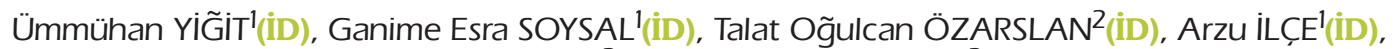 \\ Fatma SIRMATEL 2(II), Hayrettin AKDENIZ2(ID)
}

\author{
${ }^{1}$ Bolu Abant İzzet Baysal Üniversitesi Sag̃lık Bilimleri Fakültesi, Hemșirelik Bölümü, Bolu, Türkiye \\ ${ }^{2}$ Bolu Abant İzzet Baysal Üniversitesi Tıp Fakültesi, İnfeksiyon Hastalıkları ve Klinik Mikrobiyoloji Anabilim Dalı, Bolu, Türkiye
}

Makale atıfi: Yiğit Ü, Soysal GE, Özarslan TO, ilçe A, Sırmatel F, Akdeniz H. Oje kullanımının eldeki bakteriyel üreme üzerine etkisi. FLORA 2021;26(3):528-36.

ÖZ

Giriş: infeksiyonların önlenmesinde ameliyathane ve yoğun bakım gibi özellikli birimlerde çalışanların el hijyeninin sağlanması oldukça önemli, en etkili ve en ucuz yöntemdir. Bu çalışma; ameliyathane ve yoğun bakımlarda hemşirelerin oje kullanımının ellerdeki bakteriyel üreme üzerine etkisini belirlemek amacıyla planlandı.

Materyal ve Metod: Çalışmanın evrenini bir ilde bulunan eğitim araştırma ve devlet hastanesinin yoğun bakım ünitelerinde ve ameliyathanelerinde çalışan hemşireler oluşturdu. Çalışma yoğun bakımlarda 43, ameliyathanelerde 29 olmak üzere çalışmaya katılmayı kabul eden toplamda 72 hemşirede gerçekleştirildi. Araştırmaya katılanların el florası üzerindeki bakteri kolonizasyonunu ölçmek için hemşirelerinden önce ojesiz hijyenik el yıkama sonrası ilk örnek, oje sürüldükten 24 saat sonra hijyenik el yıkama sonrası ikinci örnek ve oje sürüldükten 72 saat sonra hijyenik el yıkama sonrası üçüncü örnek alındı. Hemşirelerin tırnak ve ellerinden alınan örnekler kanlı agar besiyerlerine ekilerek sonuçlar değerlendirildi.

Bulgular: Hemşirelerden üç aşamada alınan örneklerde, toplam üreyen koloni sayısı açısından bakıldığında gruplar arası hem sağ ve sol el, hem de sağ ve sol tırnaklarda, istatistiksel olarak anlamlı bir fark olmadığı görüldü $(p \geq 0.05)$. Alınan örneklerde koagülaz negatif stafilokok (KNS), Staphylococcus aureus, Bacillus spp., Enterococcus spp., Streptococcus pyogenes, Acinetobacter spp., Klebsiella spp., Candida spp. ve Non-candida mantar türlerinin ürediği tespit edildi. Bu türler arasında en sık üreyen mikroorganizmanın KNS olduğu görüldü. Ayrıca üreyen toplam koloni sayıları açısından yoğun bakım ve ameliyathaneler karşılaştırıldığında sağ el, sağ ve sol tırnaklarda fark görülmezken, sol elde üreyen toplam koloni sayısı ameliyathanede çalışan hemşirelerde anlamlı şekilde daha yüksek bulundu ( $p \leq 0.05$ ).

Sonuç: Ameliyathane ve yoğun bakım hemşirelerinde bütünlüğü bozulmamış oje kullanımının 72 saate kadar eldeki bakteriyel üreme üzerine etkisinin olmadığı bulundu.

Anahtar Kelimeler: El hijyeni; Ameliyathane; Yoğun bakım; Hemşire; Sağlık bakım ilişkili infeksiyonlar 


\title{
ABSTRACT \\ Effect of Use of Nail Polish on Hand Bacterial Colonization
}

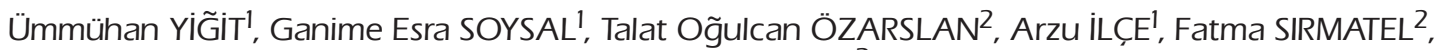 \\ Hayrettin AKDENIZ
}

\footnotetext{
${ }^{1}$ Department of Nursing, Bolu Abant İzzet Baysal University Faculty of Health Sciences, Bolu, Turkey

${ }^{2}$ Department of Infectious Diseases and Clinical Microbiology, Bolu İzzet Baysal Universityb Faculty of Medicine, Bolu, Turkey
}

\begin{abstract}
Introduction: In the prevention of infections, hand hygiene is a very important, the most effective and inexpensive method. In studies on the use of nail polish, its impact on hand hygiene is not clear. The aim of this study was to determine the effect of nail polish use of nurses in operating rooms and intensive care units on bacterial growth in hands.
\end{abstract}

Materials and Methods: The universe of the study was the nurses working in intensive care units and operating theaters. The study was conducted with 72 nurses; 43 of the participants were in the intensive care and 29 were nurses working in operating rooms. The bacterial colonization of the hand flora was measured. The samples were taken from the hands in three stages: after hand washing without nail polish; after social hand washing in 24 hour after nail polish and after social hand washing in 72 hours after nail polish. The samples were then inoculated in blood agar.

Results: When the samples were taken in three stages, there was no statistically significant difference between the groups in both right and left hand and right and left nails $(p \geq 0.05)$. In the samples, Coagulase negative staphylococci (CNS), S. aureus, Bacillus spp., Enterococcus spp., Streptococcus pyogenes, Acinetobacter spp., Klebsiella spp., Candida spp. and Non-candida yeast species were detected. CNS was the most common microorganism among these species. In addition, no difference was observed in the right hand, right and left nails compared to the intensive care and operating rooms in terms of total number of colonies. The total number of colonies in the left hand was significantly higher in the operating room nurses ( $p \leq 0.05)$.

Conclusion: When these findings were examined, there was no difference in the operating room and intensive care nurses. The use of nail polish did not appear to affect the bacterial growth in the hand.

Key Words: Hand hygiene; Operating room; Intensive care unit; Nurse; Healthcare-associated infections

\section{GíRiş}

Sağlık bakımı iliskili infeksiyonlar, önemli bir sağllk sorunudur ve bu infeksiyonların olușmasının arkasındaki nedenlerden birisi sağlık calıșanlarının yetersiz el hijyenidir ${ }^{[1]}$. Mikroorganizmalar çŏ̆u zaman sağlık calıșanlarının elleriyle tașınmakta ve bu yolla sağllk hizmetiyle ilișkili infeksiyon oranları artmaktadır ${ }^{[2]}$. Semmelweis 1843 yilında el yıkamasını sart koșarak maternal mortalitenin \%22'den \%3'e düșmesini sağlayarak sağllk alanında el yıkamanın önemini ilk kez gözler önüne sermistitr $^{[3]}$

Cerrahi alan infeksiyonları mortalite ve morbiditeyi artırmaktadır. Bu nedenle cerrahi alan infeksiyonları hastanede yatıs süresini ve hastane masraflarını artırması bakımından cerrahinin cok önemli ve cok ciddi bir problemidir. El hijyeninin doğru sağlanmaması cerrahi alan infeksiyonlarının artmasına neden olmaktadır ${ }^{[4]}$. Ameliyathanelerde ve yoğun bakımlarda patojen mikroorganizmalar kolonize ve infekte hastalardan personelin ellerine geçerek hastane içinde yayilmaya neden olurlar. İnfeksiyonların önlenmesinde ameliyathane ve yoğun bakım gibi özellikli birimlerde calıșanların el hijyeninin sağlanması en etkili, en ucuz ve oldukça önemli bir yöntemdir ${ }^{[5]}$.

Ellerin yıkanması üc ayrı grupta sınıflandırılır. Bunlar sosyal el yıkama, hijyenik el yıkama ve cerrahi el yıkamadır. Sosyal el yıkama; sadece su ve sabun kullanarak en az 10 saniye mekanik hareketler yardımıyla geçici mikroorganizmaların büyük bir coğunluğunun uzaklaștırılmasıdır. Hijyenik el yıkama en az 15 saniye ellerin sabun, antimikrobiyal sabun ya da alkol bazlı antiseptikler yardımıyla yıkanmasıdır ${ }^{[6]}$. Cerrahi el yıkama ise; geçici mikroorganizmaların öldürülüp uzaklaștırılması, kalıcı mikroorganizmaların ise olabildiğince azaltılması amaciyla ameliyathanede ellerin su ve antiseptik özelliği olan ajanlar ile yıkanarak fırçalanması esasına dayanır. 
Tüm cerrahi girișimlerden önce cerrahi el y1kama gerçeklestirilmelidir ${ }^{[3,6]}$. Hastalık Önleme ve Koruma Merkezi (Centers for Disease Control and Prevention, $\mathrm{CDC}$ ) ve Perioperatif Hemșireler Birliği (Association of Perioperative Registered Nurses, AORN) tarafindan hazırlanmıs pek cok rehberde de cerrahi el y1kamayla ilgili öneriler mevcuttur ${ }^{[7,8]}$. Cerrahi el yıkamanın etkili olabilmesi için bazı önlemler alınmalıdır. Cerrahi el yıkamanın sağlanması cerrahi el yıkama, deri bakımı, tırnak bakımı, eldiven giyilmesi, takıların c1karılması, antiseptik ürün seçimi gibi parametreleri içermektedir ${ }^{[9,10]}$. Ellerde; yüzük kullanımı, takma tırnak ve oje kullanımının mikroorganizmaların üzerine etkisiyle ilgili farklı görüșler mevcuttur. El yıkamanın öncesi ve sonrasında, gram-negatif organizmaların elle tassınması, takma tırnak kullanan kissilerde, sigara kullananlardan daha fazla olduğu tespit edilmiștir ${ }^{[11]}$.

AORN, kanıta dayalı hazırladığı verilerde ameliyathanede oje varlhğının el hijyeninin etkinliğini etkileyip etkilemediğiyle ilgili kanıtlarda; ojenin temizlenmesi gerektiğini Kanı $1 \mathrm{C}$ düzeyinde (randomize kontrollü çalıșmaların sistematik derlemesi ve/veya tek randomize kontrollü çalıșma) olduğunu bildirmektedir. Buna karșın Cochrane Kütüphanesi tarafından yayınlanan rehberlerde Kanıt 1 C düzeyinin güçlü bir sonuc olmadığını, bu nedenle alanda yapilan calismaların artırılmas1 gerektiğini bildirmektedir ${ }^{[12,13]}$. Bu calıșmalarla benzer sekilde Tank ve Celik yaptığı calıșmada; cerrahi el yıkama sonrası oje sürülen ve oje sürülmeyen ellerden alınan örneklerdeki bakteri sayları arasında istatistiksel olarak anlamlı bir farklllı bulunmadığını bildirmektedir. Bu çalıșmada koloni sayımı eldiven içine giren ellerde yapılmıstır [14]. Ameliyathane calıșanları ameliyattan önce cerrahi el yıkama yapsa da ameliyattan sonra eldiven c1karttıktan sonra ve ameliyat aralarında hijyenik el yıkama yapmaktadır. Sonuc olarak; ameliyathane ve yoğun bakım gibi özellikli birimlerde çalıșan hemșirelerin el tırnaklarına sürdüğü ojenin mikroorganizmalar üzerine etkisiyle ilgili literatürde yeterli kanıt bulunmamaktadır.

Yoğun bakım ünitelerinde ise el yıkama alıskanliklarının istenen düzeyde olmadığı, el temizliğiyle ilgili kurallara uyumun son derece düsüuk olduğu, alkol bazlı el dezenfektanlarının oldukça az kullanıldı- $\breve{g} 1$ ve gereksiz veya yanlıș eldiven kullanıldığı bildirilmektedir ${ }^{[15,16]}$. Ameliyathanede olduğu gibi; yoğun bakımlarda da uzun ve takma tırnakların infeksiyon yayılımını artırdığı, bu nedenle sağlık bakım hizmeti verenlerin kısa, bakıml, doğal tırnakları olması gerektiği bildirilmektedir ${ }^{[17]}$. Cok sayıda calıșma, takma tırnakların salgınlara yol açabilen patojenik mikroorganizmalar tarafından kolonize olabileceğini bulmuștur. Ancak literatürde oje kullanımın ellerdeki bakteriyel üreme üzerine etkisini inceleyen kanit olușturan çalıșmaya rastlanmamıștır.

$\mathrm{Bu}$ calıșma; hemșirelerinin oje kullanımının ellerde bakteriyel üreme üzerine etkisini belirlemek amaciyla yürütülmüștür.

\section{MATERYAL ve METOD}

Calıșmanın yürütülebilmesi için ildeki yerel klinik araștırmalar etik kurulundan ve hastaneden gerekli izinler alındı. Calıșmaya katılan hemșireler calıșmayla ilgili bilgilendirilerek yazılı ve sözlü onayları alınd.

Deneysel olarak tasarlanan bu calıșma bir eğitim araștırma hastanesi ve devlet hastanesinin ameliyathane ve yoğun bakım birimlerinde 12.04.2017-12.07.2017 tarihleri arasında yürütüldiu. Ameliyathane ve yoğun bakımda çalıșan hemșirelerden gönüllü olanlar çalıșmaya dahil edildi.

Çalıșmaya;

- 18 yas üstünde olan,

- Elinde cilt irritasyonu ya da lezyonu olmayan,

- Takma tırnak kullanmayan

- Tirnaklari 2 mm'den kisa olan

- Tırnaktaki ojeleri yıpranmamıs ya da bütünlüğü bozulmamıs olan

- Son iki hafta içerisinde antibiyotik kullanmamıs olan,

- Lateks alerisi olmayan,

- Calıșmaya katılmayı gönüllü kabul eden hemșireler dahil edildi.

Calıșmanın yöntemi araștırmacılar tarafından belirlenmiștir. Calıșmada öncelikli olarak hemșirelerin ellerinden, ojesiz hijyenik el yıkama sonrası kültür örnekleri alındı. Bu grup kontrol grubu olarak kabul edildi. Daha sonra, oje sürüldükten 
24 saatte sonra hijyenik el yıkama sonrası ikinci örnekler alındı (Deney grubu 1). Son örnek oje sürüldükten 72 saat sonra hijyenik el y1kama sonrası tekrar kuiltürler alındı (Deney grubu 2). Bütün hemsirelerde en az 15 saniye süreyle sabun, antimikrobiyal sabun ya da alkol bazlı antiseptikler ile el yıkama yapılmıștır.

Kültürler araștırmaya katılanların el florası üzerindeki bakteri kolonizasyonunu ölçmek için steril eküvyonlarla sürüntü alınarak, izole edilen bakterinin tanımlanması morfolojik ve gram boyanma özelliklerine ve katalaz, koagülaz ve oksidaz üretim yeteneklerine göre yapıld. Alınan örnekler besiyerine ekilerek sonuçlar değerlendirildi.

Besiyerine her hemșireden alınan örnek akıșı:

Kontrol grubu: Ojesiz hijyenik el yıkama sonrasi $(n=72)$

Deney grubu 1: Oje sürüldükten 24 saat sonra hijyenik el yıkama sonrası $(n=37)$

Deney grubu 2: Oje sürüldükten 72 saat sonra hijyenik el yıkama sonrası $(n=14)$

Örneklerin alınması ve kanlı agarda incelenmesi: Mantar ve bakteri infeksiyonlarının tırnağı tutma bölgelerine göre örnekler deneklerin iki elinden ve on parmağının tırnaklarından alındı. Her seferinde her kișiden toplam 10 ayrı sürüntü kültuirü alındı. Sürüntü alınmadan önce tüm dacron eküvyonlara $1 \mathrm{ml}$ steril serum fizyolojik emdirilerek, örnekler her elin bes tırnağının üzerine ve subungual bölgeye sürülerek alındı. Örnekler ekim islemine kadar stuart tașıma besiyerinde saklandı. Üreyen bakteriler plakta koloni sayımı seklinde gözle sayılarak değerlendirildi.

Tırnaklardan alınan örneklerden koyun kanl agar ve Eosin methylene blue (EMB) besiyerlerine her el için ayrı olmak üzere azaltarak ekim yapıldı. Deneklerin parmak ucları ve tırnaklarından ayrı olacak sekilde, koyun kanlı agar (Orbak, ORPET 07, Cağdaş 06 Sağlık Hizmetleri Ltd. Şti.) ile EMB besi yerlerine (Orbak, OR-PET 25, Çă̆daș 06 Sağlık Hizmetleri Ltd. Ști.) bes saniye süreyle bastırılarak parmak uclarındaki bakterilerinin ekimi yapıldı. Örneklerin ekildiği petriler $37^{\circ} \mathrm{C}$ 'de 24-48 saat enkübasyona birakıldı. Enkübasyonun ardından, besiyerlerinde üremede ml'de kaç koloni görüldü ise gözle sayılarak ml'de koloni sayımı yapılarak değerlendirildi. Üreme sonrası mikroorganizmalar koloni morfolojileri ve Gram boyanma özelliklerine göre tanımlandı. Gram-pozitif bakteriler için katalaz ve koagülaz testleri, gram-negatif bakterilerin identifikasyonunda ise oksidaz testi ve Triple Sugar Iron (TSI) agar kullanıld. Enterococcus identifikasyonu için Pyrolidonly-beta naphilamide (PYR) testi uyguland. Maya identifikasyonu için Germ-tube testi uyguland. Bu ișlemde tüpler $37^{\circ} \mathrm{C}$ 'de iki saat inkübasyonun ardından incelendi.

Calıșmamızda ojesiz hijyenik el yıkama sonrası alınan örnek sayısı 72 iken, oje sürülduikten 24 saat sonra hijyenik el yıkama sonrası alınan örnek sayısı 37, oje sürüldükten 72 saat sonra hijyenik el yıkama sonrası alınan örnek sayısı 14'tür. Örnek sayısındaki bu azalma ameliyathane ve yoğun bakım hemșirelerinin oje kullanımını istememeleri nedeniyledir ve çalıșmanın sınırlılığını olușturmaktadır.

\section{İstatiksel Analiz}

Elde edilen veriler SPSS (Statistical Package for the Social Sciences) 22.0 programinda kodlanarak sayı, yüzde, ki-kare, $\mathrm{t}$ testi ile istatistiksel değerlendirme gerçekleștirildi.

\section{BULGULAR}

Calıșmaya Eğitim ve Araștırma Hastanesi $(\mathrm{EAH})$ ve Devlet Hastanesi $(\mathrm{DH})$ ameliyathanelerinden 29 hemșire ve yoğun bakım ünitelerinden 43 hemșire olmak üzere 72 kiși katıldı (Tablo 1).

Tablo 1. Çalışmaya katılan hemşirelerin çalıştığı birimlere göre dağııımı $(n=72)$

\begin{tabular}{|c|c|c|c|c|c|c|}
\hline \multirow[t]{2}{*}{ Hastane/Bölüm } & \multicolumn{2}{|c|}{$\mathrm{EAH}^{*}$} & \multicolumn{2}{|c|}{$\mathrm{DH}^{*}$} & \multicolumn{2}{|c|}{ Toplam } \\
\hline & $\mathbf{n}$ & $\%$ & $\mathbf{n}$ & $\%$ & $\mathbf{n}$ & $\%$ \\
\hline Ameliyathane & 17 & 23.6 & 12 & 16.7 & 29 & 40.3 \\
\hline Yoğun bakım & 20 & 27.7 & 23 & 31.9 & 43 & 59.7 \\
\hline Toplam & 37 & 51.4 & 35 & 48.6 & 72 & 100 \\
\hline
\end{tabular}


Kontrol grubu için alınan örneklerde, EAH yoğun bakımda calıșan hemșire gurubunda sağ el parmaklarından alınan örneklerde üreyen KNS koloni sayısının $(10.25 \pm 15.44)$, DH yoğun bakım (53.05 \pm 54.54) ve $\mathrm{DH}$ ameliyathanede çalıșan hemșirelerden alınan örneklerde üreyen koloni sayısından $(81.67 \pm 72.92)$ anlaml olarak daha düșük olduğu görülürken $(p<0.05)$ sol el parmaklarından alınan örneklerde anlamlı bir farkllığa rastlanmadı. Benzer sekilde mikroorganizma ayırt etmeden kontrol grubu için alınan örneklerde, EAH yoğun bakım hemșirelerinin sağ parmaklarından alınan örneklerdeki toplam koloni sayılarının (11.65 \pm 17.13$)$, DH yoğun bakım hemșirelerinin sağ parmaklarından alınan örneklerdeki toplam koloni sayılarından (71.13 \pm 71.13) anlaml olarak daha düșük olduğu görülmüștür $(p<0.05)$. Ayrica üreyen toplam koloni sayıları açısından yoğun bakım ve ameliyathaneler karș1laștırıldığında kontrol grubunda sağ el, sağ ve sol tırnaklarda fark görülmezken sol el parmaklarda üreyen toplam koloni sayısı ameliyathanede calıșan hemsirelerde anlamlı sekilde daha yüksek bulundu ( $\mathrm{p} \leq 0.05)$.

Alınan örneklerde her üc calıșma grubunda da KNS, S. aureus, Bacillus spp., Enterococcus spp., Streptococcus pyogenes, Acinetobacter spp., Klebsiella spp., Candida spp. ve Non-candida mantar türlerinin ürediği tespit edildi. Bu türler arasında en sık üreyen mikroorganizmanın KNS olduğu görüldü (Tablo 2).

Bir kontrol (ojesiz) ve iki deney (ojeli 24. saat ve ojeli 72. saat) grubu karșlaștırıldığında; sağ, sol tırnaklardan ve sol parmaklardan alınan örneklerde koloni sayılarında gruplar arasında anlamlı bir farkllllk görülmedi.

Calıșma grupları arasında yapilan incelemelerde mikroorganizmaların 0. , 24. ve 72 . saatlerdeki koloni sayıları arasında anlamlı bir fark görülmedi. Mikroorganizmaların üreme insidansları karșlaștırıldığında 0 . saatte sağ parmaktan alınan örneklerde üreyen KNS insidansının EAH yoğun bakımda diğer gruplardan anlamlı olarak daha düșük olduğu, deney grubu 1 örneklerinde sol tırnaktan alınan örneklerde KNS insidansının DH ameliyathane grubunda diğer gruplardan anlaml olarak daha yüksek olduğu görüldü $(p<0.05)$ (Tablo 3). Mikroorganizmaların üreme insidansları karșılaștırıldığında 0. saatte sağ parmaktan alınan örneklerde üreyen $S$. pyogenes insidansının $\mathrm{DH}$ yoğun bakım grubunun diğer gruplardan anlamlı olarak daha yüksek olduğu görülmüștür $(p<0.05)$. Deney grubu 2 örneklerinde, sol ve sağ parmaklardan alınan örneklerde $S$. pyogenes insidans1nın DH ameliyathane grubunda diğer gruplardan anlamlı olarak daha yüksek olduğu görüldü $(p<$ 0.05).

\section{TARTIȘMA}

Sağlık bakım ilișkili infeksiyonların ve cerrahi alan infeksiyonlarının önlenmesinin en etkili yolu el yıkamadır. Ellerdeki mikroorganizmaların büyük çoğunluğunun tırnaklarda olduğu bildirilmektedir. Dünya Sağllk Örgütü, ameliyathanede çalıșan sağlık calıșanlarının tırnak uzunluğunun $(\leq 0.5 \mathrm{~cm})$ kısa tutulmasını ve takma tırnak kullanılmaması gerektiğini son yayınladığı rehberde belirtirken oje kullanımı konusunda kesin bir karar bildirilmemiştir $^{[18]}$.

Wynd ve arkadașları ojesiz, yeni sürülmüs oje, yıpranmıs oje ve dört gün önce sürülmüs ojeye sahip sağlık calıșanlarıyla yaptıkları calıșmalarında, yıpranmıs oje ve dört gün önce sürülmüs ojeli sağlık calıșanlarının tırnaklarında bakteri kolonizasyonunun anlamlı olarak yüksek olduğunu bulmușlardır ${ }^{[19]}$. Tank ve Celik ameliyathanede çalıșan hemșireler ile yaptıkları calıșmalarında cerrahi el yıkama sonrası oje sürülen sağ elden ve oje sürülmeyen sol ellerinden hemșirelerin ameliyathanede steril olarak bir saat calıstıktan sonra ellerini kontamine etmeden steril eldivenleri cıkarılarak alınan örneklerdeki bakteri sayılarını karșılaștırmıșlardır. Sonucunda her iki elden alınan örnekler karșilaștırıldığında istatistiksel olarak bir fark bulunmamıștır ${ }^{[14]}$. Ameliyathane calısanları ameliyattan önce cerrahi el yıkama yapsa da ameliyattan sonra eldiven c1karttıktan sonra ve ameliyat aralarında hijyenik el yıkama yapmaktadır. Calıșmamızda ameliyathane ve yoğun bakım hemșirelerinde, oje sürüldükten 72 saat sonra hijyenik el yikama sonrası alınan örneklerde elde bakteri üremesi, ojesiz hijyenik el yıkama sonrası alınan örneklere göre artıs gösteriyor olsa da bu artı̣ istatistiksel olarak anlamlı bulunmadı.

Hardy ve arkadașları veterinerlik öğrencileriyle yaptıkları calıșmalarında cerrahi süreçlerde oje kullanan grup ile kullanmayan grupta ellerin fir- 


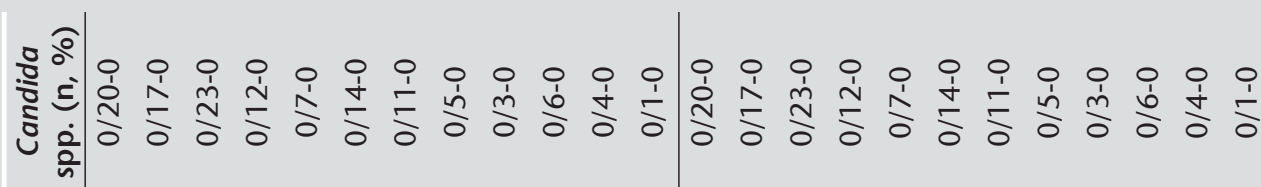

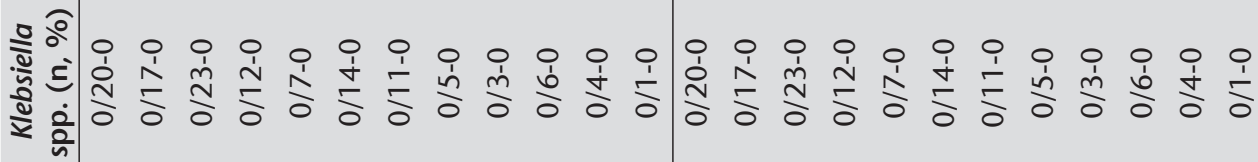

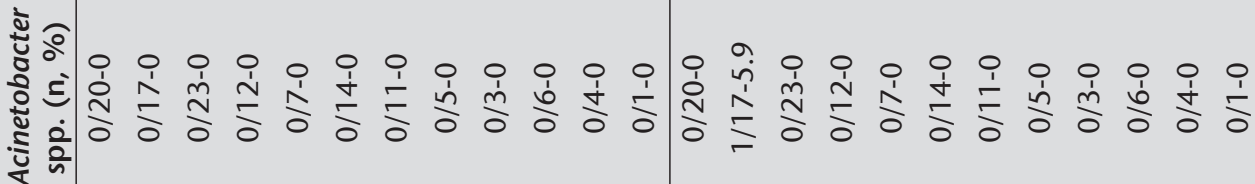

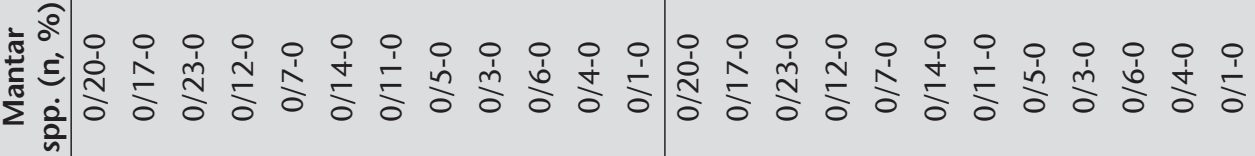

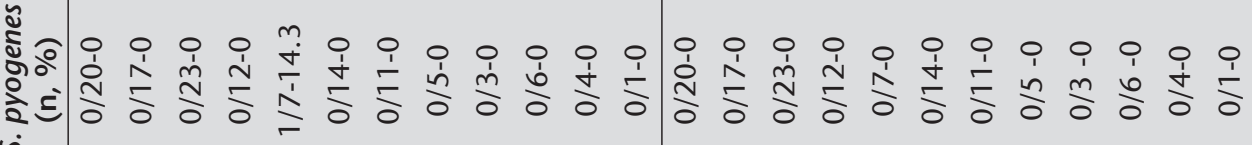

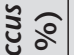

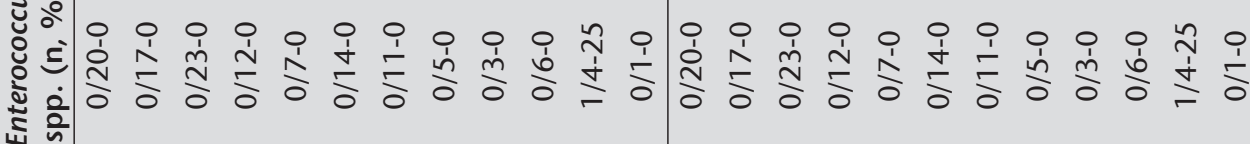

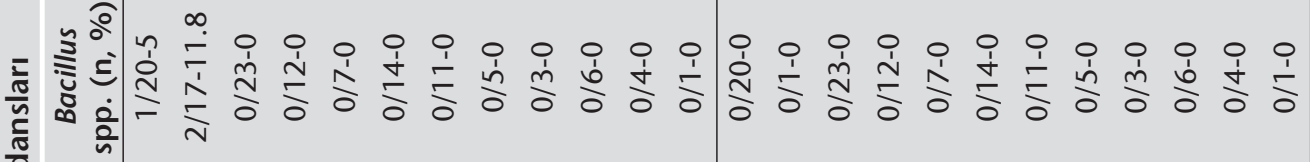

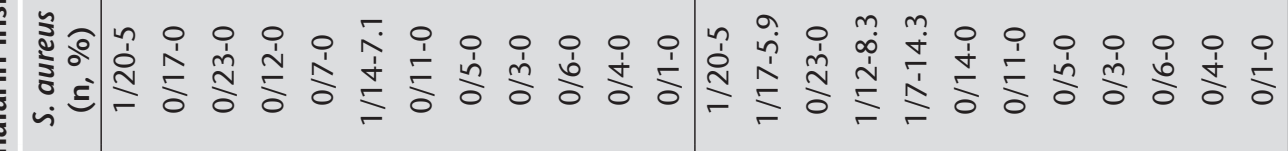

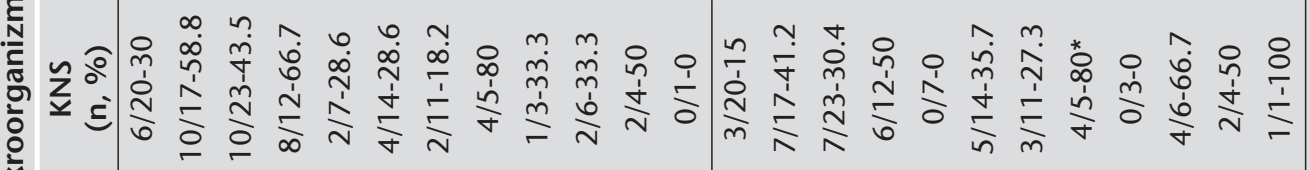

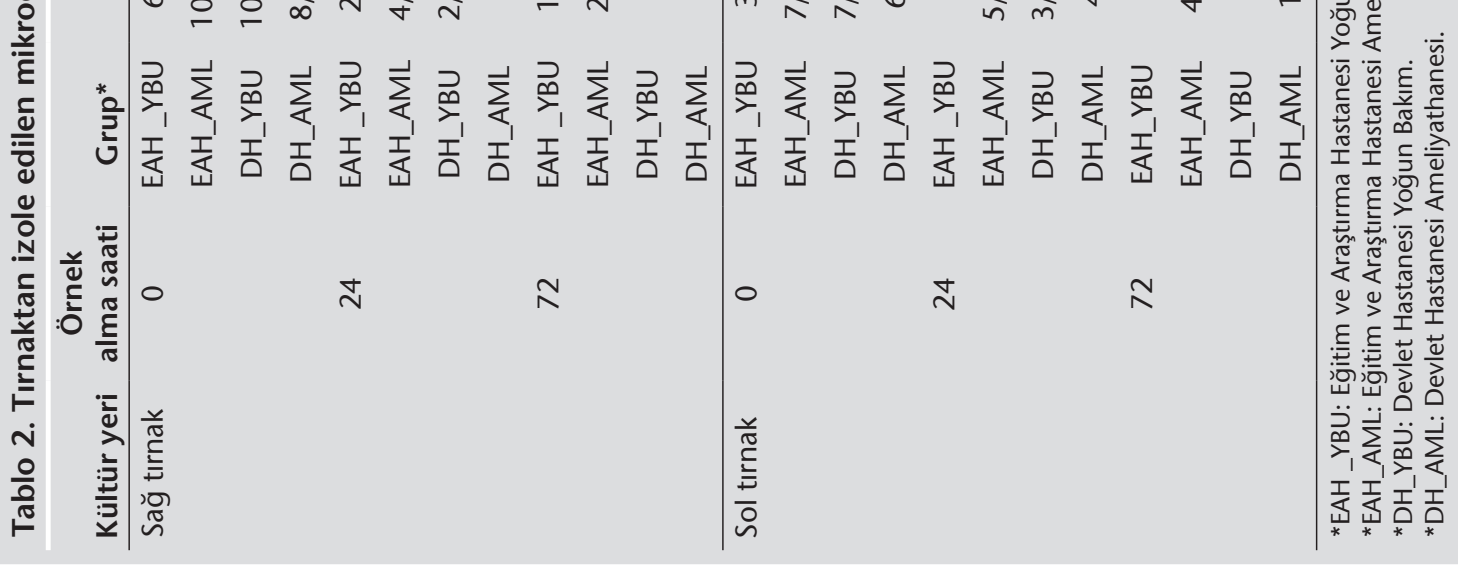


Tablo 3. Örneklerin alınma süresine göre saatteki koloni sayılarının dağılımı

\begin{tabular}{|c|c|c|c|c|c|c|}
\hline Etken & $\begin{array}{l}\text { Üreme } \\
\text { bölgesi }\end{array}$ & $\begin{array}{c}\text { Örnek alma } \\
\text { saati }\end{array}$ & $n^{*}$ & Ort & Ss. & $\begin{array}{c}\text { Ortalama } \\
\text { sıra }\end{array}$ \\
\hline & Sağ parmak & 0 & 8 & 67.2 & 76.3 & 1.8 \\
\hline & & 24 & 8 & 58.5 & 36.3 & 1.8 \\
\hline & & 72 & 8 & 72.5 & 69.3 & 2.2 \\
\hline & Sol parmak & 0 & 8 & 56.6 & 60.8 & 60.8 \\
\hline \multirow[t]{11}{*}{ KNS } & & 24 & 8 & 60.7 & 47.5 & 47.5 \\
\hline & & 72 & 8 & 80.7 & 67.9 & 67.9 \\
\hline & Sol tırnak & 0 & 2 & 2.5 & 0.7 & 2.5 \\
\hline & & 24 & 2 & 1.5 & 0.7 & 1.7 \\
\hline & & 72 & 2 & 1.5 & 0.7 & 1.7 \\
\hline & Sağ parmak & 0 & 13 & 57.6 & 77.1 & 2.0 \\
\hline & & 24 & 13 & 52.0 & 49.7 & 1.8 \\
\hline & & 72 & 13 & 76.1 & 97.6 & 2.1 \\
\hline & Sol parmak & 0 & 13 & 43.1 & 55.2 & 1.7 \\
\hline & & 24 & 13 & 54.3 & 50.5 & 2.0 \\
\hline & & 72 & 13 & 75.7 & 94.7 & 2.2 \\
\hline \multirow[t]{6}{*}{ Toplam } & Sağ tırnak & 0 & 13 & 3.4 & 10.7 & 2.0 \\
\hline & & 24 & 13 & 6.7 & 15.6 & 1.8 \\
\hline & & 72 & 13 & 3.6 & 7.7 & 2.1 \\
\hline & Sol tırnak & 0 & 13 & 13.5 & 40.8 & 1.9 \\
\hline & & 24 & 13 & 6.2 & 17.5 & 1.9 \\
\hline & & 72 & 13 & 3.6 & 6.2 & 2.1 \\
\hline
\end{tabular}

çalama öncesi, fırçalama sonrası ve cerrahi ișlem sonrası alınan örneklerinde bakteri sayıları acısından anlamlı farkllık olmadığını bildirmekler beraber tırnak uzunluğunun $2 \mathrm{~mm}$ altında tutulmasını önermektedirler. Calıșmalarında tırnak uzunluğu 2 $\mathrm{mm}$ üzerinde olanlarda bakteri sayısının anlamlı olarak yüksek olduğu görülmüstüür ${ }^{[20]}$. Fagerner ve Lingaas, eldeki mikroflorays etkileyen etmenleri belirlemek için farklı birimlerdeki 465 sağlık calısanıyla gerçeklestirdikleri calıșmalarında, ișe bașladıktan iki saat sonra ilk örnek ve gün içinde ikinci örnek olmak üzere iki kez örnek almıșlardır. Calıșmalarında ojenin eldeki mikroflora üzerine etkisinin olmadığını, ancak tırnak uzunluğunun 2 mm'den daha kısa olması gerektiğini bildirmișler$\mathrm{dir}^{[21]}$. Yeni sürülen ojenin, periungual derideki bakteri sayısını artırmadığı, ancak yıpranmış ojenin, tırnaklarda daha fazla sayıda organizmanın büyümesini destekleyebileceği bildirilmektedir ${ }^{[22-24]}$.
Tank ve Celik, literatürün aksine tırnak uzunluğu 2 mm'den küçük olan hemșirelerin ellerindeki bakteri sayısını daha yüksek bulmușlardır. Bu durumu örneklem sayısının az olmasına ve tırnak uzunluğu 3 mm'den yüksek hemșire örneklemlerinde bulunmamasına bağlamıșlardır ${ }^{[14]}$.

İzole edilen mikroorganizmaların koloni sayıları değerlendirildiğinde KNS koloni saylarının EAH yoğun bakımda, DH yoğun bakımda toplam koloni sayılarının anlamlı olarak diğer bölümlerden düșük olduğu görüldü $(p<0.05)$. EAH'deki hemșirelerden alınan örneklerden izole edilen koloni sayısının devlet hastanesi sonuclarına göre daha düșük olması hastanelerdeki farklı hijyen uygulamalarına, sağlık calıșanlarına verilen eğitimlere ve sağlık calıșanlarının calıștığı bölümlerde uygulanan dezenfeksiyon yöntemlerine bağlı olabilir. Her ne kadar KNS koloni sayılarında iki hastane ve bölümleri arasında farkllık görülmüs olsa da patojen olarak kabul edi- 
len bakteri ve mantar türlerinin koloni sayılarında bir farklılı̆̆a rastlanmadı. İki hastane arasında KNS ve toplam koloni miktarlarında görülen farklılığın sebeplerinin araștırılması olası sağlık bakım ilișkili infeksiyonların önüne geçmede yararlı olabilir.

El üzerinde, deride en cok kolonize olan bakteri türlerinin S. aureus, Staphylococcus epidermidis, Enterrococcus spp., Acinetobacter spp., Klebsiella spp., Escherichia coli türleri olduğu bilinmektedir. Tirnakta ise en sik izole edilen bakteri $S$. epidermidis iken onu Bacillus spp. S. aureus ve Candida spp. takip etmektedir. Bu calıșmada parmak ve tırnaklarda en cok üreyen bakteri türlerinin KNS ve S. aureus olduğu görüldü (Tablo 2). KNS üreme insidanslarına bakıldığına, kontrol grubu parmak örneklerinde en düșük insidansın 11 (\%55) ile EAH yoğun bakım gurubunda olduğu, en yüksek insidansin ise 12 (\%100) ile $\mathrm{DH}$ ameliyathane grubunda olduğu görülmektedir. Calıșmamızda, tırnak örneklerindeki üreme insidanslarının parmak örneklerindekinden düșük olduğu görülmektedir. Kontrol grubu tırnak örneklerindeki KNS insidans toplamda 57 (\%39.6) iken parmak örneklerinde bu oran 120 (\%83.3) olarak görülmektedir. S. aureus insidanslarına bakıldığında yine tırnak insidansının (\%2.8) parmak insidansından (\%13.2) düșük olduğu görülmektedir. Toplam patojenlere bakıldığında göre ojesiz hijyenik el yıkama sonrası alınan örneklerde parmak insidansı 57 (\%39.6), tırnak insidans sekiz (\%5.6), oje sürülduikten 24 sonra hijyenik el yıkama sonrası parmak insidansı 36 (\%48.6), tırnak insidansı üc (\%4.05), oje sürüldükten 72. saat sonra hijyenik el yıkama sonrası parmak insidansı 15 (\%53.6), tırnak insidansı iki (\%7.1) olarak bulundu. Yukarıda yazdığı gibi insidanslar ojesiz tırnak $\% 5$, oje +24 saat $\% 4$, oje +72 saat $\% 7$ seklindedir. $\% 4$ ve \%5 arasında anlamlı bir farklllik yoktur, dolayısıyla ojeli tırnaktaki \%1'lik düșuss az sayıdaki örneklem de dikkate alınarak yok kabul edilmelidir.

KNS ve $S$. aureus insidanslarına olduğu gibi S. aureus, Bacillus spp., Enterococcus spp., $S$. pyogenes, Acinetobacter spp., Klebsiella spp., Candida spp. ve Non-Candida mantar türlerini içeren toplam patojen insidansında da tirnaktan izole edilen bakteri insidansının parmaktan izole edilene göre daha düșük olduğu görülmektedir. Michigan Üniversitesi'nde sağlık calıșanlarının katılımıyla yapılan bir calıșmada tırnak üzerinden ve subungual bölgeden alınan örneklerde izole edilen toplam patojen insidansı \%35, yapay tirnak kullananlarda ise \%86 olarak bulunmustur ${ }^{[25]}$. Walaszek ve arkadașları kullanılan oje farklılıklarının da (ultraviyole ve hibrit gibi) el hijyeninin sağlamada etkili olduğunu bildirirken tırnak uzunluğunun önemli olduğunu vurgulamıșlardır[1]. Sonuçlar karșılaștırıldığında bu çalıșmada kontrol grubundan alınan örneklerde patojen insidansları \%5.6, deney grubu 1 için \%4.05 ve deney grubu 2 için \%7.1 olarak bulunmus ve literatüre göre oranın daha düșük olduğu görülmektedir. Özellikle kontrol gruplarında tırnak örneklerindeki üreme insidanslarının parmak örneklerindekinden düșük olmasının, bütünlüğü bozulmamıs ojenin tırnaklarda bakteriyel üremeyi azaltması nedeniyle olduğu görüldui.

Tank ve Celik ameliyathanede calıșan hemșirelerle yaptıkları calıșmalarında örneklem sayısının az olması nedeniyle hemșirelerin sağ ellerine oje sürerek bir saat ameliyathanede çalıșmalarını sağlamıs. Bu esnada sol ellerin ojesiz bırakmıslar ve kontrol grubu olarak almıșlardır ${ }^{[14]}$. Calıșmamızda sağ ve sol ele aynı protokol uygulanmıștır. Calıșma grupları arasında sağ, sol tırnaklardan ve sol parmaklardan alınan örneklerde koloni sayılarında anlamlı bir farklılık görülmedi.

Sonuc olarak; ameliyathane ve yoğun bakım hemșirelerinde yıpranmamıș/bütünlüğu bozulmamıs oje kullanımının 24. ve 72. saatlerde üreme insidansını veya üreyen bakterilerin koloni sayısını anlamlı sekilde arttırmadığı görülüyor olsa dahi 72. saat grubundaki örneklem sayısının düșüklüğünün bu sonuca sebep vermiș olduğu göz önünde bulundurulmalıdır. Hemșirelerden hijyenik el yıkama sonrası oje kullanımı olmadan alınan örneklerle oje kullanımı sonrası 24 ve 72 saatlerde alınan örneklerdeki sonuçlarda ojenin eldeki bakteriyel üreme üzerine etkisi olmadığı görüldü.

Cerrahi alan infeksiyonlarını ve yoğun bakım infeksiyonlarının hasta ve sağlı sistemi açısından önemi düșünüldüğünde bu sonuçlar doğrultusunda araștırmanın daha büyük örneklem grubunda yapılması önerilebilir.

\section{ETIK KURUL ONAYI}

$\mathrm{Bu}$ çalıșma, Abant İzzet Baysal Úniversitesi Klinik Araștırmalar Etik Kurul onayı ile gerçekleștirildi (Tarih: 28.09.2017, Karar No: 2017/56). 


\section{ÇIKAR ÇATIȘMASI}

Yazarlar arasında herhangi bir çıkar catıșması bulunmamaktadır.

\section{YAZAR KATKISI}

Anafikir/Planlama: ÜY, GES, Aİ, FS Analiz/Yorum: UUY, GES, Aİ, FS, TOÖ

Veri Sağlama: Tüm yazarlar

Yazım: UYY, GES, TOÖ

Gözden Geçirme ve Düzeltme: Aİ, FS

Onaylama: Tüm yazarlar

\section{KAYNAKLAR}

1. Walaszek MZ, Kolpa M, Rozanska A, Jagiencarz-starzec B, Wolak Z. Nail microbial colonization following hand disinfection : a qualitative pilot study. I Hosp Infect 2018;100:207-10.

2. Gök F, Hergül FK, Özbayır T. Surgical hand washing: A systematic review. Int J Antisep Disinfect Steril 2016;1(1):23-32.

3. Günaydın M. El hijyeni. ANKEM Derg 2012;26(Ek 2):306-8.

4. Yıldırım N, Tapan B, Gayef A, Sezen A, Alıcı S, Kayan Tapan T. Applications for the Prevention of Nosocomial Infections and a Hospital Practice. The Journal of Tepecik Education and Research Hospital 2015;25(17):93-100.

5. Süzük S, Edis Ç, Çalık A, Akdoğan S, Ünal S. The Compliance Rates of Hand Hygiene in Intensive Care Unit and Surgical Services at a State Hospital in Turkey. I Turk Soc Intens Care 2015;13(1):107-11.

6. Çopur B. El Yıkama Çeşitleri ve Dikkat Edilecek Hususlar. 4. Ulusal Sterilizasyon Dezenfeksiyon Kongresi. Published online 2005:282-6.

7. Boyce JM, Pittet D. Guideline for Hand Hygiene in Health-Care Settings: Recommendations of the Healthcare Infection Control Practices Advisory Committee and the HICPAC/SHEA/APIC/IDSA Hand Hygiene Task Force 2017;23.

8. Centers for Disease Control and Prevention 2014 National and State Healthcare-Associated Infections Progress Report; 2016.

9. Alcan AO. Cerrahi El Yıkama. In: Gıersbergen MY Van, Kaymakçı Ş, eds. Ameliyathane Hemşireliği. $1^{\text {st }}$ ed. Meta Basım Matbaacılık Hizmetleri 2015:417-23.

10. Pearson ML. Guideline for hand hygiene in healthcare settings. J Am Coll Surg 2004;198(1):121-7.

11. Canham L. Ten Misconceptions About Infection Control. The Dental Assistant. Published online 2014:8-15.

12. Girard N. Evidence appraisal of Arrowsmith VA, Taylor R. Removal of nail polish and finger rings to prevent surgical infection (Review). Cochrane Database Syst Rev 2014:8:CD003325.
13. Arrowsmith VA, Maunder JA, Taylor R. Removal of nail polish and finger rings to prevent surgical infection. Cochrane database of systematic reviews (Online). 2001;(8):CD003325.

14. Tank DY, Çelik S. Effect of use of nail polish on bacterial colonization after surgical handwashing in operating room nurses : a preliminary study. Cukurova Med J 2018;43(3):698-705.

15. Arda B, Şenol Ş, Taşbakan MI, et al. Ege Üniversitesi Tıp Fakültesi yoğun bakım ünitelerinde el temizliği kurallarına uyumun değerlendirilmesi. Yoğun Bakım Derg 2005:5(3):182-6.

16. Yorganci K, Elker D, Kaynaroğlu V. Personelinin el yıkama alışkanlıkları. Yoğun Bakım Derg 2002;2(1):58-63.

17. Gupta A, Della-latta P, Todd B, Gabriel PS, Haas J. Outbreak of extended-spectrum beta-lactamase-producing klebsiella pneumoniae in a neonatal intensive care unit linked to artificıal naıls. Inf Control Hosp Epıdemıl 2004;25(3):210-215.

18. WHO. Guidelines on hand hygiene in health care. First global patient safety challenge clean care is safer care. Gene$v a$, Switzerland World Health Organization.

19. Wynd CA, Samstag DE, Anna Mane Lapp. Bacterial carriage on the fingernails of OR nurses. AORN J 1994;60:796-805.

20. Hardy JM, Owen TJ, Martinez SA, Jones LP, Davis MA. The effect of nail characteristics on surface bacterial counts of surgical personnel before and after scrubbing. Vet Surg 2017;46(7):952-61.

21. Fagernes $M$, Lingaas $E$. Factors interfering with the microflora on hands: A regression analysis of samples from 465 healthcare workers. J Adv Nurs 2011;67(2):297-307.

22. Baumgardner CA, Maragos CS, Walz MIA, Larson E. Effects of nail polish on microbial growth of fingernails. dispelling sacred cows. AORN Journal 1993;58(1):84-88.

23. Centers for Disease Control and Prevention (CDC). Guideline for hand hygiene in health-care settings. Recommendations and Reports.

24. Wynd CA, Samstag DE, Lapp AM. Bacterial carriage on the fingernails of or nurses. AORN journal (Published online) 1994:796-805.

25. Shelly A. McNeil, Foster CL, Hedderwick SA, Kauffman CA. Effect of hand cleansing with antimicrobial soap or alcohol-based gel on microbial colonization of artificial fingernails worn by health care workers. Pediatr Infect Dis I 2001;32(1):822.

\section{Yazıșma Adresi/Address for Correspondence}

Dr. Ümmühan YíĞì

Bolu Abant İzzet Baysal U̇niversitesi

Sağlık Bilimleri Fakültesi, Hemșirelik Bölümü,

Bolu-Türkiye

E-posta: umhnygt@gmail.com 